\title{
Highly Oxygenated Guaianolides and Eudesman-12-oic Acids from Balsamorhiza sagittata and Balsamorhiza macrophylla
}

\author{
Abou El-Hamd H. Mohamed, ${ }^{a}$ Ahmed A. Ahmed, ${ }^{*}, b$ Eckhard Wollenweber, ${ }^{c}$ Bruce Bohm, ${ }^{d}$ and \\ Yoshinori AsAKAWA ${ }^{e}$ \\ ${ }^{a}$ Department of Chemistry, Aswan-Faculty of Science, South Valley University; Aswan, Egypt: ${ }^{b}$ Department of Chemistry, \\ Faculty of Science, El-Minia University; El-Minia 91516, Egypt: ${ }^{c}$ Institut für Botanik der Technischen Universtät; \\ Schnittspahnstrasse 3, D-64287 Darmstadt, Germany: ${ }^{d}$ Botany Department, University of British Columbia; Vancouver, \\ B.C., Canada: and ${ }^{e}$ Faculty of Pharmaceutical Sciences, Tokushima Bunri University; Yamashiro-cho, Tokushima \\ 770-8514, Japan. Received July 13, 2005; accepted October 15, 2005
}

Investigation of lipophilic exudates from the aerial parts of Balsamorhiza sagittata and $B$. macrophylla afforded three new highly oxygenated guaianolides $(1-3)$, in addition to known guaianolides, germacranolide and eudesmane acids. Their chemical structures were elucidated by spectroscopic methods and the data for the compounds are reported in Tables 1 and 2 and in Experimental.

Key words Balsamorhiza sagittata; Balsamorhiza macrophylla; Asteraceae; highly oxygenated guaianolide; eudesmanic acid

The genus Balsamorhiza has been placed in different subtribes of the large tribe Heliantheae within the Astercease. $^{1-3)}$ Balsamorhiza sagittata [Pursch] NutTall is commonly known as arrowleaf balsamroot. Flavonoids, ${ }^{4)}$ guaianolides, heliangolides, diterpenes, cycloartenol derivatives $^{5)}$ and antibacterial thiophene ${ }^{6)}$ have been reported from this species. Six known methylated flavonols were isolated from the leaf of cut leaf balsamroot, B. macrophylla. ${ }^{7)}$ Further fractionation of the extract of aerial parts of Balsamorhiza sagittata and Balsamorhiza macrophylla resulted in the isolation of three new guaianolide type sesquiterpenes, in addition to several known compounds. Here we report their structural elucidation.

Separation of the terpenoid portion of the resinous exudate of $B$. sagittata [PURSCH] NuTT. on a silica gel open column yielded three new guaianolides, 2-deoxo-5-deoxy-8-Oacetyl-17,18 epoxy pumilin (1), 2-deoxo-8- $O$-acetyl pumilin (2) and methyl-9 $\beta$-(epoxyangeloyloxy)-5 $\alpha, 6 \alpha$-dihydroxy-2oxo-3,4-dehydro- $\delta$-guaien-12-oate (3), in addition to the known compounds 17,18 -epoxy-8- $O$-acetyl pumilin $(4),{ }^{5)} 8$ $O$-acetyl pumilin (5), ${ }^{8)}$ and $9 \beta$-acetoxy-3-epi-nobiliun (6). ${ }^{5}$ Investigation of the exudate terpenoids of $B$. macrophylla afforded three known eudesmanic acids, 3-oxo-eremophila9,11(13)dien-12-carboxylic (7), ${ }^{9)}$ 3-oxo eremophila-4,11(13) dien-12-oic (8) ${ }^{10)}$ and 10-hydroxy-3-oxoeremophila-1,11(13) dien-12-oic acids (9). ${ }^{9}$ )

ESI-ICR mass spectrum of compound 1 exhibited a molecular ion peak $[\mathrm{M}+\mathrm{Na}]^{+}$at $\mathrm{m} / \mathrm{z} 425$ and exact mass at $\mathrm{m} / \mathrm{z}$ 425.1567, establishing the elemental composition as $\left[\mathrm{C}_{22} \mathrm{H}_{26} \mathrm{O}_{7} \mathrm{Na}\right]^{+}$. Its IR spectrum showed an absorption band at $1752 \mathrm{~cm}^{-1}$ ( $\gamma$-lactone). The ${ }^{1} \mathrm{H}$-NMR spectrum of compound 1 revealed a signal at $\delta 3.63(\mathrm{t}, J=10.5 \mathrm{~Hz}, \mathrm{H}-6)$, correlated in ${ }^{1} \mathrm{H}-{ }^{1} \mathrm{H}$ COSY with two signals at $\delta_{\mathrm{H}} 3.46(\mathrm{brd}$, $J=10.5 \mathrm{~Hz}, \mathrm{H}-5)$ and $3.33(\mathrm{t}, J=10.5 \mathrm{~Hz}, \mathrm{H}-7)$, suggesting the presence of a $\mathrm{C}_{5} \mathrm{H}-\mathrm{C}_{6} \mathrm{H}(\mathrm{O})-\mathrm{C}_{7} \mathrm{H}$ moiety. Additionally, the signal at $\delta_{\mathrm{H}} 5.24(\mathrm{t}, J=10.5 \mathrm{~Hz}, \mathrm{H}-8)$ correlated with two signals at $\delta_{\mathrm{H}} 3.33(\mathrm{t}, J=10.5 \mathrm{~Hz}, \mathrm{H}-7)$ and 5.53 (brd, $J=10.5 \mathrm{~Hz}, \mathrm{H}-9$ ), indicating the presence of a $\mathrm{C}_{7} \mathrm{H}-\mathrm{C}_{8} \mathrm{H}(\mathrm{O})-\mathrm{C}_{9} \mathrm{H}(\mathrm{O})$ moiety. Accordingly, compound $\mathbf{1}$ contained a $\mathrm{C}_{5} \mathrm{H}-\mathrm{C}_{6} \mathrm{H}(\mathrm{O})-\mathrm{C}_{7} \mathrm{H}-\mathrm{C}_{8} \mathrm{H}(\mathrm{O})-\mathrm{C}_{9} \mathrm{H}(\mathrm{O})$ moiety. Furthermore, the ${ }^{1} \mathrm{H}-\mathrm{NMR}$ displayed signals for an epoxy an- gelate moiety as a doublet at $\delta 1.40(J=5.5 \mathrm{~Hz}, \mathrm{H}-19)$, quartet at $\delta 3.09(J=5.5 \mathrm{~Hz}, \mathrm{H}-18)$ and singlet at $\delta 1.52(\mathrm{H}-20)$. The ${ }^{13} \mathrm{C}$-NMR spectrum exhibited 22 carbon signals which were classified by a DEPT experiment as follows: three quaternary carbonyl carbons at $\delta 169.0,169.9$ and 169.6 for C$12, \mathrm{C}-16$ and the carbonyl carbon of acetate, five methyl carbons at $\delta 15.4,17.9,14.3,19.9$ and 21.2 for C-14, C-15, C$19, \mathrm{C}-20$ and the methyl carbon of acetate, and five oxygenated carbons at $\delta 82.1,70.3,74.6,59.6$ and 61.2 for C-6, C-8, C-9, C-17 and C-18, respectively. The connectivity of the partial moieties and the positions of acyl groups, epoxyangelate and acetate, and the $\mathrm{C}_{6,12}$-lactonization were
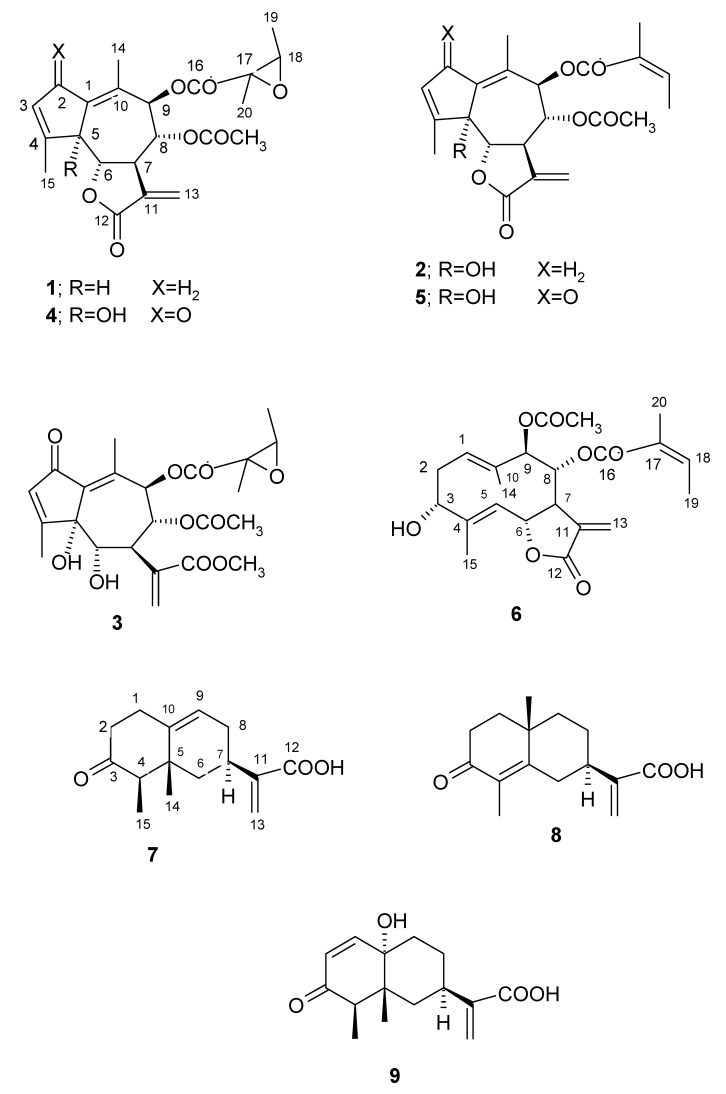

(C) 2006 Pharmaceutical Society of Japan 


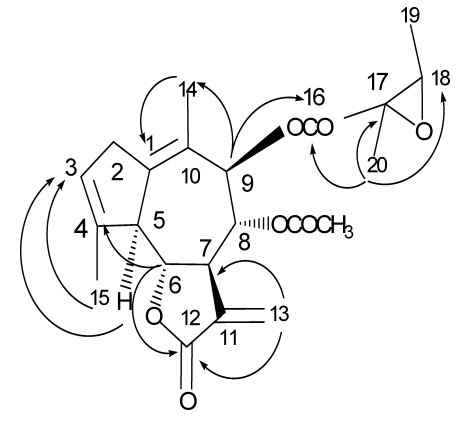

Fig. 1. Selected HMBC Correlations of $\mathbf{1}$

established by the HMBC spectrum of $\mathbf{1}$. In this spectrum $\mathrm{C}-\mathrm{H}$, correlations were found between the protons of the exomethylene group (H-13a and $\mathrm{H}-13 \mathrm{~b})$ and $\mathrm{C}-7\left(\delta_{\mathrm{C}} 53.8\right)$ and C-12 $\left(\delta_{\mathrm{C}} 169.0\right)$; between H-5 and C-3 $\left(\delta_{\mathrm{C}} 126.6\right), \mathrm{C}-4\left(\delta_{\mathrm{C}}\right.$ $139.9)$, C-6 $\left(\delta_{\mathrm{C}} 82.1\right)$ and $\mathrm{C}-7\left(\delta_{\mathrm{C}} 53.8\right)$; and between $\mathrm{H}-2$ and $\mathrm{C}-3\left(\delta_{\mathrm{C}} 126.6\right)$. The correlation between $\mathrm{H}-6$ and $\mathrm{C}-4$ $\left(\delta_{\mathrm{C}} 139.9\right)$ and $\mathrm{C}-12\left(\delta_{\mathrm{C}} 169.0\right)$ supported the $\mathrm{C}_{6,12}$-lactonization. Additionally, $\mathrm{HMBC}$ experiments (Fig. 1) showed correlations between $\mathrm{H}-15$ and $\mathrm{C}-3\left(\delta_{\mathrm{C}} 126.6\right), \mathrm{C}-4\left(\delta_{\mathrm{C}} 139.9\right)$ and $\mathrm{C}-5\left(\delta_{\mathrm{C}} 54.7\right)$; between $\mathrm{H}-14$ and C-1 $\left(\delta_{\mathrm{C}} 126.3\right)$, C-9 $\left(\delta_{\mathrm{C}} 74.6\right)$ and $\mathrm{C}-10\left(\delta_{\mathrm{C}} 140.1\right)$; between $\mathrm{H}-19$ and C-18 $\left(\delta_{\mathrm{C}}\right.$ 61.2); between $\mathrm{H}-20$ and $\mathrm{C}-16\left(\delta_{\mathrm{C}} 169.9\right)$ and $\mathrm{C}-18\left(\delta_{\mathrm{C}}\right.$ $61.2)$; and between $\mathrm{H}-9$ and $\mathrm{C}-16\left(\delta_{\mathrm{C}} 169.9\right)$ which supported the location of the epoxyangelate group at C-9. Furthermore, all proton and carbon signals were determined by ${ }^{1} \mathrm{H}-{ }^{1} \mathrm{H}$ COSY, HMQC and HMBC (Tables 1,2 ). The stereochemistry of $\mathbf{1}$ was determined from the observed coupling constants and NOE. The relative stereochemistry at C-5, C-6, C-7, C-8 and C-9 were derived from the coupling constants $\left(J_{5,6}=J_{6,7}=J_{7,8}=J_{8,9}=10.5 \mathrm{~Hz}\right)$, which were in agreement with the anti-diaxial disposition of the protons at C-5 $(\alpha)$, C$6(\beta)$, C-7 $(\alpha)$, C-8 $(\beta)$ and C-9 $(\alpha)$. Clear NOE were observed between H-6 and H-8 indicating the $\beta$-orientation of these protons. Irradiation of the signal at $\delta 3.46(\mathrm{H}-5)$ enhanced signals at $\delta 3.33$ (H-7) and H-9 at $\delta 5.53$, which suggested the $\alpha$-orientation of H-5, H-7 and H-9. Therefore, compound (1) was identified as 2-deoxo-5-deoxy-8- $O$-acetyl17,18 epoxy pumilin.

The ESI-ICR-MS of $\mathbf{2}$ gave a molecular ion peak $[\mathrm{M}+\mathrm{Na}]^{+}$at $\mathrm{m} / \mathrm{z} 425$ and exact mass determination at $\mathrm{m} / \mathrm{z}$ 425.1560 , which established the elemental composition as $\mathrm{C}_{22} \mathrm{H}_{26} \mathrm{O}_{7} \mathrm{Na}^{+}$. The IR spectrum showed absorption bands at $3446(\mathrm{OH})$, and $1777 \mathrm{~cm}^{-1}$ ( $\gamma$-lactone). The NMR spectral data of compound $\mathbf{2}$ were quite similar to those of compound 1. Differences indicated the presence of an angelate group in $\mathbf{2}$, instead of epoxy angelate in $\mathbf{1}$, from the typical angelate signals at $\delta 6.22(\mathrm{q}, \mathrm{H}-18), 2.02(\mathrm{dq}, \mathrm{H}-19)$ and $1.87(\mathrm{q}, \mathrm{H}-$ 20). The ${ }^{13} \mathrm{C}-\mathrm{NMR}$ and DEPT experiments exhibited 22 carbon signals. Among them, four oxygenated methine carbon signals appeared at $\delta 81.8,83.4,69.7$ and 72.7 assigned for C-5, C-6, C-8 and C-9, respectively, two methylene carbon signals at 35.8 and 120.5 for C-2 and C-13, five methyl carbon signals at 15.7, 13.9, 20.5, 16.0 and 20.5 assigned for $\mathrm{C}$ $14, \mathrm{C}-15, \mathrm{C}-19, \mathrm{C}-20$ and methyl of acetate, respectively, and three quaternary carbon signals at $\delta 168.8,166.5$ and 169.9 assigned for C-12, C-16 and the carbonyl carbon of acetate, respectively. Again, the connectivity of these partial moieties, the positions of acyl groups, angelate and acetate, and the $\mathrm{C}_{6,12}$-lactonization were determined by the HMBC spectrum of 2. The HMBC spectrum showed important correlations between $\mathrm{H}-2$ and $\mathrm{C}-1\left(\delta_{\mathrm{C}} 129.9\right)$ and $\mathrm{C}-10\left(\delta_{\mathrm{C}} 138.8\right)$; between H-3 and C-2 $\left(\delta_{\mathrm{C}} 38.5\right), \mathrm{C}-4\left(\delta_{\mathrm{C}} 142.4\right)$ and C-5 $\left(\delta_{\mathrm{C}}\right.$ $81.8)$; and between the exomethylene protons and C-7 $\left(\delta_{\mathrm{C}}\right.$ 45.7), $\mathrm{C}-11\left(\delta_{\mathrm{C}} 137.0\right)$, and $\mathrm{C}-12\left(\delta_{\mathrm{C}} 168.8\right)$. The correlation between H-6 and C-5 $\left(\delta_{\mathrm{C}} 81.8\right), \mathrm{C}-7\left(\delta_{\mathrm{C}} 45.7\right)$ and C-12 $\left(\delta_{\mathrm{C}}\right.$ 168.8), supported the $\mathrm{C}_{6,12}$-lactonization. Also, the HMBC spectrum showed correlations between $\mathrm{H}-9$ and $\mathrm{C}-8\left(\delta_{\mathrm{C}}\right.$ 69.7), $\mathrm{C}-14\left(\delta_{\mathrm{C}} 15.7\right)$ and $\mathrm{C}-16\left(\delta_{\mathrm{C}} 166.5\right)$ which supported the location of the angelate at $\mathrm{C}-9$. Moreover, it displayed correlations between $\mathrm{H}-15$ and $\mathrm{C}-3\left(\delta_{\mathrm{C}} 127.4\right), \mathrm{C}-4\left(\delta_{\mathrm{C}}\right.$ $142.4)$ and $\mathrm{C}-5\left(\delta_{\mathrm{C}} 81.8\right)$; and between $\mathrm{H}-14$ and $\mathrm{C}-1\left(\delta_{\mathrm{C}}\right.$ $129.9), \mathrm{C}-9\left(\delta_{\mathrm{C}} 72.7\right)$ and $\mathrm{C}-10\left(\delta_{\mathrm{C}} 138.8\right)$. All proton and carbon signals were determined by ${ }^{1} \mathrm{H}-{ }^{1} \mathrm{H}$ COSY, HMQC and HMBC (Tables 1,2). The stereochemistry was proved by the coupling constants. The $\alpha$-orientation of the hydroxyl group at C-5 was suggested from the downfield shift of $\mathrm{H}-7 \alpha$ and $\mathrm{H}-9 \alpha$, compared with the signals of $\mathrm{H}-7$ and $\mathrm{H}-9$ in compound 1. ${ }^{5,11)}$ Therefore, compound $\mathbf{2}$ was identified as 2 deoxo-8-O-acetyl pumilin.

The EI-MS of compound 3 exhibited a molecular ion peak $[\mathrm{M}]^{+}$at $\mathrm{m} / \mathrm{z} 464$ and exact mass at $\mathrm{m} / \mathrm{z} 464.1683$, which established the elemental composition as $\mathrm{C}_{23} \mathrm{H}_{28} \mathrm{O}_{10}$. Compound 3 had NMR spectral data similar to compound 4 (Tables 1,2$)$. However, the ${ }^{1} \mathrm{H}-\mathrm{NMR}$ spectrum revealed the presence of two broad singlet signals at $\delta 5.80$ and 6.40. The absence of a correlation between these two signals and H-7 in ${ }^{1} \mathrm{H}-{ }^{1} \mathrm{H}$ COSY suggested that compound $\mathbf{3}$ had an ester function instead of the lactone moiety $\left(\mathrm{C}=\mathrm{O}, \mathrm{IR}: v=1720 \mathrm{~cm}^{-1}\right)$. Additionally, the ${ }^{1} \mathrm{H}-\mathrm{NMR}$ spectrum indicated the presence of an epoxy angelate at $\delta 3.03(\mathrm{q}, \mathrm{H}-18), 1.30(\mathrm{~d}, \mathrm{H}-19)$ and 1.45 (s, H-20), a methyl ester at $\delta 3.76(\mathrm{~s})$, and an acetyl group at $\delta 2.10(\mathrm{~s})\left(\mathrm{C}=\mathrm{O}, \mathrm{IR}: v=1758 \mathrm{~cm}^{-1}\right)$. The two methyls of the sesquiterpene were found at $\delta 2.28(\mathrm{H}-14, \mathrm{~s})$ and $2.27(\mathrm{H}-15, \mathrm{~d})$. One of the methyls for $\mathrm{H}-15$ that showed correlation in ${ }^{1} \mathrm{H}-{ }^{1} \mathrm{H}$ COSY with the quartet signal at $\delta 6.19$ could be assigned for $\mathrm{H}-3$ (allylic coupling). The ${ }^{13} \mathrm{C}-\mathrm{NMR}$ spectrum and DEPT experiments displayed 23 carbons signals; 7 oxygen bearing carbons at 81.8 (s), 77.2 (d), 70.6 (d), 71.3 (d), 52.4 (q), 59.5 (s), 60.2 (d), 4 carbonyl carbons at $\delta$ 193.0, 168.5, 170.0, 173.9 (s); and 6 olefinic carbons at $\delta$ 135.3 (d), 133.3 (s), 146.8 (s), 143.9 (s), 128.3 (t), 138.5 (s). The HMBC spectrum displayed several important correlations between $\mathrm{H}-3$ and $\mathrm{C}-1\left(\delta_{\mathrm{C}} 133.3\right)$ and $\mathrm{C}-2\left(\delta_{\mathrm{C}} 193.0\right)$ and $\mathrm{C}-5\left(\delta_{\mathrm{C}} 81.8\right)$; between OMe, H-13 and C-12 ( $\left.\delta_{\mathrm{C}} 168.5\right)$; between $\mathrm{H}-6$ and $\mathrm{C}-4\left(\delta_{\mathrm{C}} 143.9\right)$ and $\mathrm{C}-11\left(\delta_{\mathrm{C}} 138.5\right)$; and between $\mathrm{H}-9$ and $\mathrm{C}-1\left(\delta_{\mathrm{C}} 133.3\right), \mathrm{C}-10\left(\delta_{\mathrm{C}} 146.8\right)$ and C-16 $\left(\delta_{\mathrm{C}} 173.9\right)$, which supported the location of the epoxy angelate at C-9. Moreover, it displayed correlations between $\mathrm{H}-15$ and $\mathrm{C}-3\left(\delta_{\mathrm{C}} 135.3\right)$; and between $\mathrm{H}-14$ and $\mathrm{C}-1\left(\delta_{\mathrm{C}} 133.3\right)$, $\mathrm{C}-9\left(\delta_{\mathrm{C}} 71.3\right)$ and $\mathrm{C}-10\left(\delta_{\mathrm{C}} 146.8\right)$. All signals were determined by ${ }^{1} \mathrm{H}-{ }^{1} \mathrm{H}$ COSY, HMQC. The stereochemistry of compound 3 was proved by coupling constants and NOESY spectrum. The anti-orientation of H-6 and $\mathrm{H}-7$ was deduced from the coupling constant $(J=11.0 \mathrm{~Hz})$. The NOESY spectrum indicated clear effects between H-7 with H-9 and H-6 with $\mathrm{H}-8$. Moreover, the $\alpha$-orientation of the hydroxyl group at C-5 was deduced from the downfield shift of the signals H-7 $\alpha$ and H-9 $\alpha .{ }^{5,11)}$ Therefore, compound 3 was established to be methyl-9 $\beta$-(epoxyangeloyloxy)- $5 \alpha, 6 \alpha$-dihydroxy-2- 
Table 1. ${ }^{1} \mathrm{H}-\mathrm{NMR}$ Spectral Data of Compounds $\mathbf{1}-\mathbf{3}$ and $\mathbf{9}\left(400 \mathrm{MHz}, \mathrm{CDCl}_{3}, \delta\right.$-Values)

\begin{tabular}{|c|c|c|c|c|}
\hline Proton & 1 & 2 & $3^{b)}$ & 9 \\
\hline 1 & & & & $6.49, \mathrm{~d}, J=10.5$ \\
\hline 2 & 3.00, br d, $J=22.0$ & 2.97, br d, $J=22.0$ & & $5.78, \mathrm{~d}, J=10.5$ \\
\hline 3 & 5.53, br s & 5.65, br s & $6.19, \mathrm{q}, J=1.5$ & \\
\hline 4 & & & & $2.84, \mathrm{q}, J=6.5$ \\
\hline 5 & 3.46, br d, $J=10.5$ & & & \\
\hline 6 & $3.63, \mathrm{t}, J=10.5$ & $4.04, \mathrm{~d}, J=11.0$ & 3.64, br d, $J=11.0$ & $\begin{array}{l}1.34, \text { br t }, J=11.5 \\
1.55, \mathrm{~m}\end{array}$ \\
\hline 7 & $3.33, \mathrm{t}, J=10.5$ & $4.08, \mathrm{tt}, J=11,3$ & $3.73, \mathrm{~m}$ & $2.56, \mathrm{t}, J=11.5$ \\
\hline 8 & $5.24, \mathrm{t}, J=10.5$ & $5.34, \mathrm{t}, J=11.0$ & $5.23, \mathrm{t}, J=11.0$ & $\begin{array}{l}1.55, \mathrm{~m} \\
1.61, \mathrm{~m}\end{array}$ \\
\hline 9 & 5.53, br d, $J=10.5$ & $6.22,{ }^{a)} \mathrm{d}, J=11.0$ & $6.38, \mathrm{~d}, J=11.0$ & $\begin{array}{l}1.78, \text { br d, } J=14.0 \\
1.92, \mathrm{dd}, J=14.0,3.5\end{array}$ \\
\hline $13 \mathrm{a}$ & $5.49, \mathrm{~d}, J=3.0$ & $5.41, \mathrm{~d}, J=3.0$ & 5.80, br s & 5.33 , br s \\
\hline $13 b$ & $6.11, \mathrm{~d}, J=3.0$ & $6.11, \mathrm{~d}, J=3.0$ & 6.40 , br s & 5.94 , br s \\
\hline 14 & $1.59, \mathrm{~s}$ & $1.62, \mathrm{~s}$ & $2.28, \mathrm{~s}$ & $0.72, \mathrm{~s}$ \\
\hline 15 & $1.91, \mathrm{~s}$ & $1.90, \mathrm{~s}$ & $2.27, \mathrm{~d}, J=1.5$ & $0.98, \mathrm{~d}, J=6.5$ \\
\hline 18 & $3.09, \mathrm{q}, J=5.5$ & $\left.6.22,{ }^{a}\right) \mathrm{qq}, J=5.5,1.5$ & $3.03, \mathrm{q}, J=5.5$ & \\
\hline 19 & $1.40, \mathrm{~d}, J=5.5$ & $2.02, \mathrm{dq}, J=5.5,1.5$ & $1.30, \mathrm{~d}, J=5.5$ & \\
\hline 20 & $1.52, \mathrm{~s}$ & $1.87, \mathrm{dq}, J=1.5,1.5$ & $1.45, \mathrm{~s}$ & \\
\hline $\mathrm{AcO}$ & $2.10, \mathrm{~s}$ & $2.00, \mathrm{~s}$ & $2.10, \mathrm{~s}$ & \\
\hline $\mathrm{MeO}$ & & & $3.76, \mathrm{~s}$ & \\
\hline
\end{tabular}

a) Overlapping signals. b) In Varian Unity $600 \mathrm{MHz}$ NMR spectrometry.

Table 2. ${ }^{13} \mathrm{C}-\mathrm{NMR}$ Data of Compounds $\mathbf{1}-\mathbf{3}, \mathbf{7}$ and $9\left(100 \mathrm{MHz}, \mathrm{CDCl}_{3}\right.$, $\delta$-Values)

\begin{tabular}{|c|c|c|c|c|c|}
\hline No. & 1 & 2 & 3 & 7 & 9 \\
\hline 1 & $126.3 \mathrm{~s}$ & 129.9 & 133.3 & $30.9 \mathrm{t}$ & $154.1 \mathrm{~d}$ \\
\hline 2 & $38.0 \mathrm{t}$ & 35.8 & $193.0 \mathrm{~s}$ & $43.1 \mathrm{t}$ & $126.6 \mathrm{~d}$ \\
\hline 3 & $126.6 \mathrm{~d}$ & 127.4 & 135.3 & $212.0 \mathrm{~s}$ & 202.9 \\
\hline 4 & $139.9 \mathrm{~s}$ & 142.4 & 143.9 & $52.7 \mathrm{~d}$ & 46.6 \\
\hline 5 & $54.7 \mathrm{~d}$ & $81.8 \mathrm{~s}$ & $81.8 \mathrm{~s}$ & $41.7 \mathrm{~s}$ & 45.7 \\
\hline 6 & $82.1 \mathrm{~d}$ & 83.4 & 77.2 & $40.2 \mathrm{t}$ & 37.3 \\
\hline 7 & $53.8 \mathrm{~d}$ & 45.7 & 52.4 & $31.5 \mathrm{~d}$ & 33.5 \\
\hline 8 & $70.3 \mathrm{~d}$ & 69.7 & 70.6 & $31.4 \mathrm{t}$ & 25.7 \\
\hline 9 & $74.6 \mathrm{~d}$ & 72.7 & 71.3 & $120.6 \mathrm{~d}$ & $33.5 \mathrm{t}$ \\
\hline 10 & $140.1 \mathrm{~s}$ & 138.8 & 146.8 & $142.2 \mathrm{~s}$ & 73.0 \\
\hline 11 & $137.1 \mathrm{~s}$ & 137.0 & 138.5 & $144.0 \mathrm{~s}$ & 128.3 \\
\hline 12 & $169.0 \mathrm{~s}$ & 168.8 & 168.5 & $172.3 \mathrm{~s}$ & 172.0 \\
\hline 13 & $120.6 \mathrm{t}$ & 120.5 & 128.3 & $125.5 \mathrm{t}$ & 120.3 \\
\hline 14 & $15.4 \mathrm{q}$ & 15.7 & 11.7 & $22.2 \mathrm{q}$ & 16.7 \\
\hline 15 & $17.9 \mathrm{q}$ & 13.9 & 16.5 & $7.5 \mathrm{q}$ & 6.9 \\
\hline 16 & $169.9 \mathrm{~s}$ & 166.5 & 173.9 & & \\
\hline 17 & $59.6 \mathrm{~s}$ & 126.8 & 59.5 & & \\
\hline 18 & $61.2 \mathrm{~d}$ & $141.5 \mathrm{~d}$ & $60.2 \mathrm{~d}$ & & \\
\hline 19 & $14.3 \mathrm{q}$ & 20.5 & 13.7 & & \\
\hline 20 & $19.9 \mathrm{q}$ & 16.0 & 19.3 & & \\
\hline $\mathrm{AcO}$ & $\begin{array}{l}\text { 169.6; } \\
21.2 \mathrm{q}\end{array}$ & $\begin{array}{c}169.9 \\
20.5\end{array}$ & $\begin{array}{c}170.0 \\
20.8\end{array}$ & & \\
\hline $\mathrm{MeO}$ & & & $52.4 \mathrm{q}$ & & \\
\hline
\end{tabular}

oxo-3,4-dehydro- $\delta$-guaien-12-oate.

Repeated chromatography of the terpenoid portion of the leaf resin of Balsamorhiza macrophylla on silica gel afforded three known eudesmanic acids $7,{ }^{9)} \mathbf{8}^{10)}$ and 9.9) The relative stereochemistry of compound $\mathbf{8}$ was determined by X-ray crystallographic analysis (Fig. 2). The methyl ester of compound 9 was reported by Zdero et al. to be a methyl ester derivative $^{9)}$ and this is the first report of 9 being a as free acid from natural source. The EI-MS spectrum of compound 9 exhibited a molecular ion peak $\left[\mathrm{M}-\mathrm{H}_{2} \mathrm{O}\right]^{+}$at $\mathrm{m} / \mathrm{z} 246$, which indicated the molecular formula $\mathrm{C}_{15} \mathrm{H}_{20} \mathrm{O}_{4}$ for 9. The ${ }^{1} \mathrm{H}$ NMR spectrum (Table 1) revealed a quartet signal at $\delta 2.84$

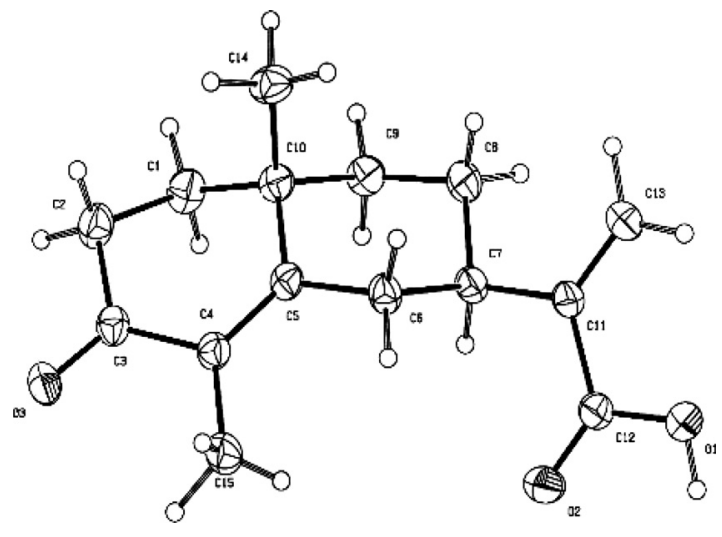

Fig. 2. ORTEP Diagram of the Crystal Structure of $\mathbf{8}$

$(J=6.5 \mathrm{~Hz}, \mathrm{H}-4)$, which showed correlation in ${ }^{1} \mathrm{H}-{ }^{1} \mathrm{H}$ COSY with a doublet at $\delta 0.98(J=6.5 \mathrm{~Hz}, \mathrm{H}-15)$. It also showed a triplet signal at $\delta 2.56(J=11.5 \mathrm{~Hz}, \mathrm{H}-7)$, indicating correlation in ${ }^{1} \mathrm{H}-{ }^{1} \mathrm{H}$ COSY with $\mathrm{H}-6$, and appeared as a broad triplet at $\delta 1.34(J=11.5 \mathrm{~Hz}, \mathrm{H}-6 \mathrm{a})$ and a multiple signal at $\delta$ 1.55 (m, H-6b). Furthermore, it showed two doublets at $\delta$ $6.49(J=10.5 \mathrm{~Hz}, \mathrm{H}-1)$ and $5.78(J=10.5 \mathrm{~Hz}, \mathrm{H}-2)$. The ${ }^{13} \mathrm{C}-$ NMR spectrum (Table 2) displayed 15 carbon signals and was classified by DEPT experiments as follows: 2 carbonyl carbon signals at $\delta 202.9$ and 172.0 assigned for C-3 and C$12 ; 2$ methyl carbon signals at $\delta 16.7$ and 6.9, assigned for C-14 and C-15; 4 methylene carbon signals at $\delta 37.3,25.7$, $33.5,120.3$, assigned for C-6, C-8, C-9 and H-13; four methine carbon signals at $\delta 154.1,126.6,46.6$, and 33.5 , a signed for C-1, C-2, C-4 and C-7, respectively, and 3 quaternary carbon signals at $\delta 45.7,73.0$, and 128.3, assigned for C-5, C10 and $\mathrm{C}-11$, respectively. HMBC indicated several correlations: $\mathrm{H}-1$ with $\mathrm{C}-3$ and $\mathrm{C}-5, \mathrm{H}-2$ with $\mathrm{C}-4$ and $\mathrm{C}-10, \mathrm{H}-4$ with $\mathrm{C}-3, \mathrm{C}-14$ and $\mathrm{C}-15, \mathrm{H}-13$ with $\mathrm{C}-7$ and $\mathrm{C}-12$, and $\mathrm{H}-14$ with $\mathrm{C}-6$ and $\mathrm{C}-10$. The presence of $\mathrm{H}-14$ upfield at 0.72 supported the $\alpha$-orientation of the hydroxyl group at $\mathrm{C}-10$. 
The unpublished ${ }^{13} \mathrm{C}$-NMR of compounds 7 and 9 are listed in Table 2.

In conclusion, the chemical investigation of the surface resin of the terpenoids of $B$. sagittata afforded guaianolides and heliangolides as its main constituents, while, B. macrophylla gave eudesmanes. The terpenoid constituents of both species appear to be consistent with the differences in the flavonoid constituents (unpublished data, Wollenweber), therefore, further species have to be investigated.

\section{Experimental}

General Experimental Procedures NMR spectra were measured with a Bruker AMX-400 ( ${ }^{1} \mathrm{H}-\mathrm{NMR}$ : $400 \mathrm{MHz},{ }^{13} \mathrm{C}-\mathrm{NMR}$ : $\left.100 \mathrm{MHz}\right)$ spectrometer and a Varian Unity $600 \mathrm{MHz}$ NMR spectrometer $\left({ }^{1} \mathrm{H}-\mathrm{NMR}\right.$ : $\left.600 \mathrm{MHz}\right)$, with TMS as an internal standard. ESI-mass spectra were acquired by means of APEX II-FIICR-MS [4.7 T, Bruker-Daltonik, Bremen, Germany]. The IR spectra [oily film, $\mathrm{CHCl}_{3}$ ] were taken on a Perkin Elmer FT-IR spectrometer. Optical rotations were measured with a Perkin-Elmer 241 Polarimeter operating at sodium D line. TLC: Precoated silica gel $60 \mathrm{~F}_{254}$ plates (Merck); Prep. TLC: silica gel $\mathrm{PF}_{254}$ (Merck, $200 \times 200 \times 0.25 \mathrm{~mm}$ ); CC: silica gel type 60 (Merck).

Plant Material Aerial parts of flowering B. sagittata (PuRsh) NutT. and B. macrophylla NuTT. were collected in the spring of 2000 in Bogus Canyon, North Logan, Cache County, Utah and were air-dried. Further material of $B$. sagittata was collected from four populations in British Columbia (Ecological Reserve, Princeton; Anarchist Mountain, Osoyoos; Okanagan Falls; Marble Canyon area. Voucher specimens have been deposited at UBC.

Extraction and Isolation Dry aerial parts of Balsamorhiza sagittata and $B$. macrophylla, respectively, were briefly rinsed with acetone to dissolve the resinous exudated material. The exudates of the four $B$. sagittata collections from British Columbia were combined since they exhibited identical terpenoid and flavonoid patterns. The solutions were evaporated to dryness, redissolved in a small volume of hot $\mathrm{MeOH}$, cooled to $-10^{\circ} \mathrm{C}$, and the precipitating material was eliminated by centrifugation. The defatted solutions were passed over Sephadex LH-20 (Pharmacia) and eluted with $\mathrm{MeOH}$ to separate the flavonoids from the more aboundant terpenoids.

The terpenoid portion of B. sagittata and B. macrophylla was fractionated by flash column chromatography $[5 \times 55 \mathrm{~cm}]$ over silica gel $[1 \mathrm{~kg}]$ eluting with hexane with an increasing amount of $\mathrm{CH}_{2} \mathrm{Cl}_{2}$. The first fraction $(100 \%$, hexane 11 ) of both species contained hydrocarbons and waxes. B. sagittata, the second fraction (hexane- $\mathrm{CH}_{2} \mathrm{Cl}_{2}, 3: 1,21$ ) gave a crude material which was purified by Sephadex LH-20 $\left(3 \times 35 \mathrm{~cm}\right.$, hexane $-\mathrm{CH}_{2} \mathrm{Cl}_{2}-\mathrm{MeOH}$ $7: 4: 0.5,300 \mathrm{ml})$ to give compounds $1(7 \mathrm{mg})$ and $5(1.5 \mathrm{mg})$. The third fraction $\left(\mathrm{CH}_{2} \mathrm{Cl}_{2}, 100 \%\right)$ was further purified by Sephadex LH-20 $\left(3 \times 35 \mathrm{~cm}\right.$, hexane- $\left.\mathrm{CH}_{2} \mathrm{Cl}_{2}-\mathrm{MeOH} 7: 4: 1,500 \mathrm{ml}\right)$ to afford the compounds $\mathbf{2}(5.3 \mathrm{mg}), \mathbf{3}(2.2 \mathrm{mg}), \mathbf{4}(6.5 \mathrm{mg})$ and $\mathbf{6}(14.5 \mathrm{mg})$. B. macrophylla, the second fraction (hexane- $\mathrm{CH}_{2} \mathrm{Cl}_{2}, 3: 1,21$ ) was purified by a Sephadex column to give compounds $7(35 \mathrm{mg}), \mathbf{8}(47 \mathrm{mg}), \mathbf{9}(7 \mathrm{mg})$.

2-Deoxo-5-deoxy-8-O-acetyl-17,18 Epoxy Pumilin (1): Yellow oil; IR $V_{\max }^{\mathrm{CHCl}_{3}} \mathrm{~cm}^{-1}: 2931,1752$ (broad), 1539, 1508.0, 1450, 1375, 1228, 1142, 1036, 736; ${ }^{1} \mathrm{H}$ - and ${ }^{13} \mathrm{C}-\mathrm{NMR}\left(400,100 \mathrm{MHz}, \mathrm{CDCl}_{3}\right)$ : Tables 1 and 2; HRESI-MS $m / z: 425.1571(\mathrm{M}+\mathrm{Na})^{+}\left(\right.$Calcd for $\mathrm{C}_{22} \mathrm{H}_{26} \mathrm{O}_{7}+\mathrm{Na}, 425.1567 ;[\alpha]_{\mathrm{D}}^{22}$ $+0.03^{\circ}\left(c=3.88, \mathrm{CH}_{2} \mathrm{Cl}_{2}\right)$.

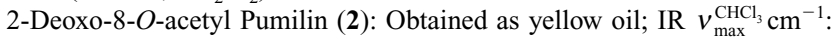
3446, 2926, 1777, 1751, 1725, 1646, 1437, 1377, 1258, 1234, 1149, 1042, 850, 738; ${ }^{1} \mathrm{H}$ - and ${ }^{13} \mathrm{C}-\mathrm{NMR}\left(400,100 \mathrm{MHz}, \mathrm{CDCl}_{3}\right)$ : Tables 1 and 2; HRESI-MS $m / z$ : $425.1571[\mathrm{M}+\mathrm{Na}]^{+}\left(\mathrm{Calcd}\right.$ for $\mathrm{C}_{22} \mathrm{H}_{26} \mathrm{O}_{7}+\mathrm{Na}, 425.1561 ;[\alpha]_{\mathrm{D}}^{22}$ $+0.024^{\circ}\left(c=2.75, \mathrm{CH}_{2} \mathrm{Cl}_{2}\right)$

Methyl-9 $\beta$-(epoxyangeloyloxy)- $5 \alpha, 6 \alpha$-dihydroxy-2-oxo-3,4-dehydro- $\delta$ guaien-12-oate (3): White oil; IR $v_{\max }^{\mathrm{CHCl}_{3}} \mathrm{~cm}^{-1}: 3448,1758,1720,1651$, $1510,1450,1370,1228,1142,1040,736 ;{ }^{1} \mathrm{H}-$ and ${ }^{13} \mathrm{C}-\mathrm{NMR}(600$, $\left.100 \mathrm{MHz}, \mathrm{CDCl}_{3}\right)$ : Tables 1 and 2; HR-EI-MS m/z: $464.1684[\mathrm{M}]^{+}$, (Calcd for $\mathrm{C}_{23} \mathrm{H}_{28} \mathrm{O}_{10}, 464.1683,[\alpha]_{\mathrm{D}}^{22}+16.72^{\circ}\left(c=0.14, \mathrm{CHCl}_{3}\right)$.

17,18-Epoxy-8-O-acetyl Pumilin (4): Colorless powder; EI-MS m/z: 432 $[\mathrm{M}]^{+}, 414,390,372,354,316,298,274,256,238,228,161,116,83,55$; ${ }^{1} \mathrm{H}-\mathrm{NMR}\left(400 \mathrm{MHz}, \mathrm{CDCl}_{3}\right): 6.28(1 \mathrm{H}, \mathrm{q}, J=1.2 \mathrm{~Hz}, \mathrm{H}-3), 3.99(1 \mathrm{H}, \mathrm{d}$, $J=10 \mathrm{~Hz}, \mathrm{H}-6), 4.14(1 \mathrm{H}, \mathrm{m}, \mathrm{H}-7), 5.40(1 \mathrm{H}, \mathrm{m}, \mathrm{H}-8), 6.28(1 \mathrm{H}, \mathrm{d}$, $J=10 \mathrm{~Hz}, \mathrm{H}-9$, overlapping), $6.25(1 \mathrm{H}, J=3.0 \mathrm{~Hz}, \mathrm{H}-13 \mathrm{a}), 5.62(1 \mathrm{H}$, $J=3.0 \mathrm{~Hz}, \mathrm{H}-13 \mathrm{~b}), 2.31(3 \mathrm{H}, \mathrm{d}, J=1.2 \mathrm{~Hz}, \mathrm{H}-14), 2.36(3 \mathrm{H}, \mathrm{d}, J=1.2 \mathrm{~Hz}, \mathrm{H}-$ 15), 3.19 (3H, q, $J=5.4 \mathrm{~Hz}, \mathrm{H}-18), 1.44(3 \mathrm{H}, \mathrm{d}, J=5.4 \mathrm{~Hz}, \mathrm{H}-19), 1.48(3 \mathrm{H}$, $\mathrm{s}, \mathrm{H}-20), 2.19(3 \mathrm{H}, \mathrm{s}, \mathrm{OAc}) ;[\alpha]_{\mathrm{D}}^{22}-1.61^{\circ}\left(c=1.8, \mathrm{CHCl}_{3}\right)$.

8-O-Acetyl Pumilin (5): Yellow oil; EI-MS $m / z$ : $416[\mathrm{M}]^{+}, 398,375,356$,
$316,274,257,256,239,228,161,83,55 ;{ }^{1} \mathrm{H}-\mathrm{NMR}\left(400 \mathrm{MHz}, \mathrm{CDCl}_{3}\right)$ : $6.17(1 \mathrm{H}, \mathrm{q}, J=1.2 \mathrm{~Hz}, \mathrm{H}-3), 3.90(1 \mathrm{H}, \mathrm{d}, J=10 \mathrm{~Hz}, \mathrm{H}-6), 4.11(1 \mathrm{H}, \mathrm{m}, \mathrm{H}-$ 7), $5.35(1 \mathrm{H}, \mathrm{t}, J=10 \mathrm{~Hz}, \mathrm{H}-8), 6.13(1 \mathrm{H}, \mathrm{d}, J=10 \mathrm{~Hz}, \mathrm{H}-9$, overlapping), $6.13(1 \mathrm{H}, J=2.8 \mathrm{~Hz}, \mathrm{H}-13 \mathrm{a}), 5.43(1 \mathrm{H}, J=2.8 \mathrm{~Hz}, \mathrm{H}-13 \mathrm{~b}), 2.24(3 \mathrm{H}, \mathrm{d}$, $J=0.7 \mathrm{~Hz}, \mathrm{H}-14), 2.27(3 \mathrm{H}, \mathrm{d}, J=1.4 \mathrm{~Hz}, \mathrm{H}-15), 6.23$ (3H, qq, $J=7.4$, $1.4 \mathrm{~Hz}, \mathrm{H}-18), 2.00(3 \mathrm{H}, \mathrm{dq}, J=7.4,1.4 \mathrm{~Hz}, \mathrm{H}-19), 1.87(3 \mathrm{H}, \mathrm{q}, J=1.4 \mathrm{~Hz}$, $\mathrm{H}-20), 2.02(3 \mathrm{H}, \mathrm{s}, \mathrm{OAc}) ;{ }^{13} \mathrm{C}-\mathrm{NMR}\left(100 \mathrm{MHz}, \mathrm{CDCl}_{3}\right): 135.0$ (C-1), 192.9 (C-2), 136.2 (C-3), 134.7 (C-4), 77.0 (C-5), 83.5 (C-6), 45.3 (C-7), 68.2 (C8), 72.6 (C-9), 146.3 (C-10), 134.7 (C-11), 168.3 (C-12), 121.0 (C-13), 12.4 (C-14), 15.3 (C-15), 166.2 (C-16), 126.4 (C-17), 141.5 (C-18), 15.9 (C-19), 20.3 (C-20), 170.2, 20.3 (OAc).

9 $\beta$-Acetoxy-3-epi-nobiliun (6): Colorless crystal; EI-MS $m / z$ : $404[\mathrm{M}]^{+}$, $344,304,244,216,179,83,55 ;{ }^{1} \mathrm{H}-\mathrm{NMR}\left(400 \mathrm{MHz}, \mathrm{CDCl}_{3}\right): 5.46(1 \mathrm{H}, \mathrm{brt}$, $J=8 \mathrm{~Hz}, \mathrm{H}-1), 2.65(1 \mathrm{H}, \mathrm{m}, \mathrm{H}-2 \beta), 2.20(1 \mathrm{H}, \mathrm{ddd}, J=8,13,13 \mathrm{~Hz}, \mathrm{H}-2 \alpha)$, $4.72(1 \mathrm{H}$, br dd, $J=5.4,11.5 \mathrm{~Hz}, \mathrm{H}-3 \beta), 5.13(1 \mathrm{H}, \mathrm{brd}, J=11 \mathrm{~Hz}, \mathrm{H}-5), 4.78$ $(1 \mathrm{H}, \mathrm{brd}, J=11 \mathrm{~Hz}, \mathrm{H}-6 \beta), 2.87(1 \mathrm{H}, \mathrm{brd}, J=10 \mathrm{~Hz}, \mathrm{H}-7 \alpha), 5.20(1 \mathrm{H}, \mathrm{t}$, $J=10 \mathrm{~Hz}, \mathrm{H}-8 \beta), 5.34(1 \mathrm{H}, \mathrm{d}, J=10 \mathrm{~Hz}, \mathrm{H}-9 \alpha), 6.32(1 \mathrm{H}, \mathrm{d}, J=1.8 \mathrm{~Hz}, \mathrm{H}-$ 13a), $5.64(1 \mathrm{H}, \mathrm{d}, J=1.8 \mathrm{~Hz}, \mathrm{H}-13 \mathrm{~b}), 1.79(3 \mathrm{H}, \mathrm{d}, J=1.2 \mathrm{~Hz}, \mathrm{H}-14), 1.85$ $(3 \mathrm{H}, \mathrm{s}, \mathrm{H}-15), 6.10(1 \mathrm{H}, \mathrm{qq}, J=7.2,1.8 \mathrm{~Hz}, \mathrm{H}-18), 1.94$ (3H, dq, $J=7.2$, $1.8 \mathrm{~Hz}, \mathrm{H}-19), 1.82(3 \mathrm{H}, \mathrm{q}, J=1.8 \mathrm{~Hz}, \mathrm{H}-20), 2.20(3 \mathrm{H}, \mathrm{s}, \mathrm{OAc}) ;{ }^{13} \mathrm{C}-\mathrm{NMR}$ $\left(100 \mathrm{MHz}, \mathrm{CDCl}_{3}\right): 126.6(\mathrm{C}-1), 32.5(\mathrm{C}-2), 67.7$ (C-3), 141.0 (C-4), 123.1 (C-5), 75.0 (C-6), 48.4 (C-7), 69.8 (C-8), 80.4 (C-9), 132.6 (C-10), 133.8 (C-11), 168.0 (C-12), 127.6 (C-13), 17.3 (C-14), 12.3 (C-15), 169.6 (C-16), 126.8 (C-17), 140.2 (C-18), 15.7 (C-19), 20.2 (C-20), 166.1, 20.8 (OAc); $[\alpha]_{\mathrm{D}}^{22}-2.96^{\circ}\left(c=2.8, \mathrm{CHCl}_{3}\right)$

3-Oxo-10-hydroxy-eremophila-1,11(13)dien-12-oic Acid (9): Yellow oil; EI-MS $m / z: 246\left[\mathrm{M}-\mathrm{H}_{2} \mathrm{O}\right]^{+}, 218,185,177,167,111,97,69,55,43 ;{ }^{1} \mathrm{H}-$ and ${ }^{13} \mathrm{C}$-NMR: Table 2.

Crystal Structure Determination of Compound 8 Crystal data: $\mathrm{C}_{15} \mathrm{H}_{20} \mathrm{O}_{3}$, formula wt. 248.31 crystal size $1.40 \times 0.20 \times 0.10 \mathrm{~mm}$, tetragonal $P 4_{2}, \quad a=6.7769(8) \AA, \quad b=6.7769(8) \AA, \quad c=29.963(3) \AA, \quad V=1376.1(3) \AA^{3}$, $Z=4, D_{\mathrm{c}}=1.199 \mathrm{gm} / \mathrm{cm}^{3}, F(000)=536, \mathrm{GOF}=1.047$. The reflection data were collected on a Siemens P4 diffractometer operating in the $\omega$ scan mode, using graphite monochromated $\mathrm{CuK \alpha}$ radiation $(\lambda=1.54056 \AA)$. The structures were solved by direct methods using Bruker SHELEX-97 (Sheldrick, 1997) and refined by full matrix least squares on $F^{2}$ using Bruker SHELXL-97 (Sheldrick, 1997). ${ }^{12)}$ The final $R$ and $R_{\mathrm{W}}$ were 0.327 and 0.879 , respectively. Crystallographic data for the structural analysis have been deposited with the Cambridge Crystallographic Data Center and allocated the deposition number CCDC 182352. These data can be obtained free of charge via www.ccdc. Cam.ac.uk/cants/retrieving html/or from the CCDC, 12 union Road, Cambridge CB2 1 EZ, U.K.; Fax: +44-1223-336033; email: deposit@ccdc.cam.ac.uk).

Acknowledgements This work was supported and financed by the Matsumae Foundation (Japanese Grant for Mr. Abou El-Hamd). We would like to thank all members of the analytical center of Tokushima Bunri University, Japan, for recording the MS and NMR spectra.

\section{References}

1) Stuessy T. J., "In the Biology and Chemistry of the Compositae," eds. by Heywood, V. H., Harborne J. B., Turner B. L., Academic Press, London, 1977, p. 634

2) Robinson A., Smithson. Contrib. Botany, 51, 48 (1981)

3) Bremer K., "Asteraceae. Cladistics and Classification," Timber Press, Portland, Oregon, 1994.

4) Bohm B. A., Choy J. B., Lee A. Y.-M., Phytochemistry, 28, 501—503 (1989).

5) Bohlmann F., Misra L. N., Jakupovic J., King R. M., Robinson H., Phytochemistry, 24, 2029-2036 (1985).

6) Matsuura H., Saxena G., Farmer S. W., Hancock R. E. W., Towers G. H. N., Planta Med., 62, 65-66 (1996).

7) McCormick S., Robinson K., Bohm B., Phytochemistry, 24, 2133 (1985).

8) Seaman F. C., Malcolm A. J., Fronczek F. R., Lee I. Y., Fischer N. H., Phytochemistry, 23, 817-822 (1984).

9) Zdero C., Bohlmann F., Anderberg A., King R. M., Phytochemistry, 30, 2643-2650 (1991)

10) Ceccherelli P., Curini M., Marcotullio M. C., Rosati O., Tetrahedron Lett., 31, 3071-3074 (1990).

11) Balboul B. A. A. A., Ahmed A. A., Otsuka H., Bando M., Kido M., Phytochemistry, 46, 1045-1049 (1997).

12) Sheldrick G. M., SHELXL97. Program for the Refinement of Crystal Structures. University of Göttingen, Germany, 1997. 